\title{
Hubungan Anemia dengan Tingkat Dismenore
}

Ropitasari, ${ }^{1}$ Isnadewi Safitri ${ }^{2}$

${ }^{1}$ Mahasiswa Program Studi D III Kebidanan Fakultas Kedokteran Universitas Sebelas Maret

${ }^{2}$ Dosen Program Studi D III Kebidanan Fakultas Kedokteran Universitas Sebelas Maret

\begin{abstract}
Abstrak
Keluhan nyeri menstruasi atau dismenore sering dijumpai pada remaja perempuan sampai mengganggu aktivitas mereka. Keluhan ini diperparah dengan kondisi anemia atau kadar hemoglobin yang kurang dari normal. Penelitian ini menggunakan metode observasional analitik dengan menggunakan uji statistik Somers'd. Sampel penelitian diambil dengan menggunakan teknik total sampling dan terdiri dari 43 responden yang memenuhi kriteria inklusi. Pengambilan data dengan mengambil sampel darah siswi untuk mengukur dan mengumpulkan data anemia oleh petugas laboratorium Surakarta pada tanggal 20 April 2015. Hasil penelitian menunjukkan siswa tingkat I yang mengalami anemia $88,9 \%$, tingkat II sebanyak $75,6 \%$ dan tingkat III sebanyak $84,6 \%$. Simpulan ada hubungan bermakna antara anemia dengan tingkat dismenore di SMA Muhammadiyah 3 Surakarta dengan kekuatan korelasi sedang $\mathrm{r}=0,426$.
\end{abstract}

Kata kunci: Anemia, tingkat dismenore 


\title{
Correlation between Anemia with Dysmenorrhea Level
}

\begin{abstract}
Menstruation or dysmenorrhea pain are common among girls to interfere with their activities. These complaints exacerbated by conditions of anemia or hemoglobin levels less than normal. This research used the observational analytical method with the cross-sectional approach. The samples of research were taken by using the total sampling technique and consisted of 43 respondents who fulfilled the inclusive criteria. Collecting data with taking blood samples to measure student and collect data anemia by laboratory personel Surakarta on 20 April 2015. The result showed student at first level are anemic $88,9 \%$, the second level are $75,6 \%$ are anemic and the third level are $84,6 \%$ are anemic. The analysis shows that the p-value was 0.000 , and the r-value was 0.426 (moderate). There was a significant correlation anemia and the dysmenorrhea level.
\end{abstract}

Keywords: Anemia, dysmenorrhea level

\section{Pendahuluan}

Keluhan nyeri saat menstruasi, seperti kram di tengah bawah rahim sampai mengganggu aktivitas tak jarang dialami oleh remaja, terutama remaja sekolah dengan tingkat aktivitas fisik yang tinggi. Keluhan nyeri tersebut dapat terjadi bervariasi mulai dari ringan sampai berat. ${ }^{1}$ Keluhan nyeri saat menstruasi dalam istilah kesehatan disebut dismenore.

Angka kejadian dismenore di Indonesia sekitar 54,89\%, sedangkan sisanya adalah penderita dengan tipe sekunder. ${ }^{2}$ Saat terjadi periode menstruasi, terdapat ketidakseimbangan penurunan estrogen/progesteron, sehingga menimbulkan efek kerusakan jaringan melalui iskemia yang mengakibatkan pengeluaran fosfolipid, asam arakidonat dan ion kalsium, serta produksi prostaglandin dan vasopressin. Hal demikian mengakibatkan dismenore. Iskemia terjadi bila aliran darah dan oksigen yang terkandung di dalamnya tidak dapat mencapai ke bagian organ tubuh tertentu. ${ }^{3}$

Hemoglobin dalam sel darah berfungsi untuk mengikat oksigen $\left(\mathrm{O}_{2}\right)$. Semakin banyak oksigen yang diikat dan dibawa ke dalam sel darah merah, pasokan oksigen ke berbagai tempat di seluruh tubuh akan tercapai sehingga mengurangi risiko terjadinya iskemia. ${ }^{4}$ Nilai normal kadar hemoglobin seorang perempuan ialah 12-16gr/dl. ${ }^{5}$ Apabila kadar hemoglobin kurang dari 12 gram \%, maka disebut dengan anemia. Anemia terbagi menjadi 3, anemia ringan (kadar hemoglobin 10 gram \%), anemia sedang apabila kadar hemoglobin 7-9 gram\% dan anemia berat apabila kadar hemoglobin kurang dari 6 gram $\% .^{5}$
Studi pendahuluan pada sepuluh siswi SMA Muhammadiyah 3 Surakarta didapatkan 20\% siswi tidak mengalami dismenore tetapi mengalami anemia ringan, $10 \%$ siswi mengalami dismenore dan tidak anemia, dan $70 \%$ siswi mengalami dismenore dengan anemia sedang. Wawancara lebih lanjut telah dilakukan terhadap delapan siswi yang mengalami dismenore, sebagian besar dari mereka mengatakan bahwa keadaan ini mengganggu aktivitas sehari-hari terutama saat pembelajaran berlangsung. Terdapat $70 \%$ siswi mengalami dismenore dengan anemia sedang membuat penulis tertarik untuk mengetahui hubungan tingkat anemia dengan tingkat dismenore pada siswi SMA Muhammadiyah 3 Surakarta.

\section{Metode}

Jenis penelitian adalah observasional analitik dengan pendekatan potong lintang. Penelitian dilakukan di SMA Muhammadiyah 3 Surakarta periode Desember 2014-Juni 2015. Populasi penelitian yaitu semua siswi yang sudah mengalami menstruasi yang bersekolah di SMA Muhammadiyah 3 Surakarta kelas X dan XI tahun ajaran 2014/2015 sejumlah 47 siswi. Teknik sampling yang digunakan adalah total sampling. Sasaran penelitian 47 responden. Namun 4 responden mengalami drop out (DO), dengan alasan 1 siswi yang tidak masuk sekolah dan 3 orang siswi sedang mengalami menstruasi sehingga sampai akhir waktu penelitian dilakukan didapatkan responden sejumlah 43 siswi.

Pengambilan data dilaksanakan dengan mengambil sampel darah pada siswi untuk 
mengukur dan mengumpulkan data mengenai kadar hemoglobin oleh petugas laboratorium daerah Kota Surakarta pada tanggal 20 April 2015. Data tingkat dismenore diambil pada saat responden mengalami menstruasi dan diisikan ke lembar observasi oleh peneliti. Waktu menstruasi responden tidak sama sehingga waktu pengisian lembar observasi juga berbeda-beda.

Analisis data penelitian ini menggunakan analisis univariat dan bivariat. Analisis univariat meliputi distribusi frekuensi, persentase anemia dan tingkat dismenore. Analisis bivariat digunakan untuk mendapatkan gambaran hubungan antara anemia dengan tingkat dismenore. Teknik analisis data dalam penelitian ini menggunakan uji statistik Somers'd yang digunakan untuk uji korelasi variabel ordinal dengan ordinal. Pada uji statistik Somers'd, hipotesis alternatif diterima apabila nilai probabilitas $(\mathrm{p})<0,05$ dan ditolak jika nilai nilai probabilitas $(\mathrm{p})>0,05$. $^{\text {? }}$

\section{Diskusi}

\section{Gambar 1 Anemia}

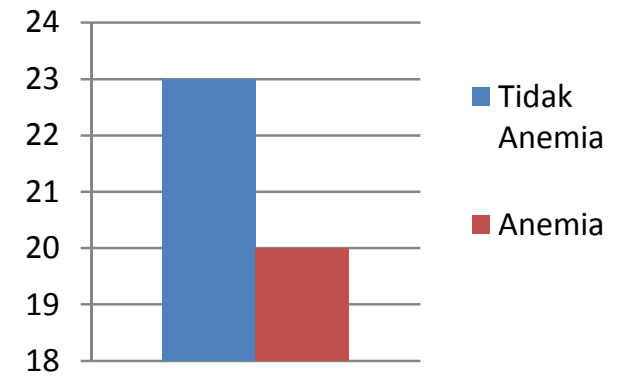

\section{Gambar 2 Tingkat Dismenore}

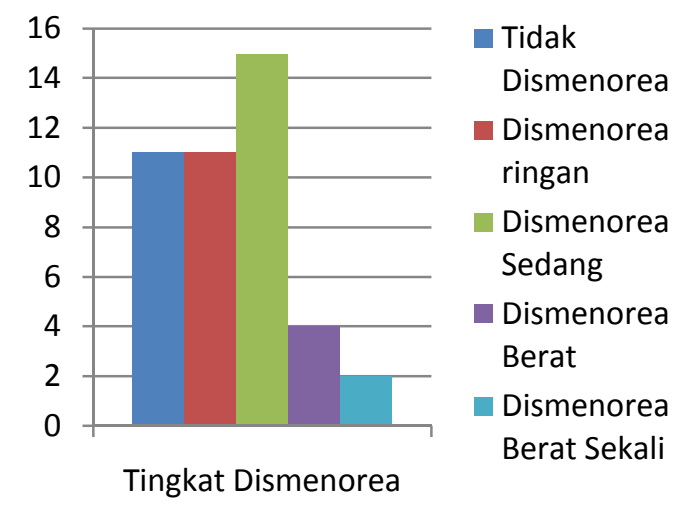

\section{Analisis Bivariat \\ Gambar 3 Hubungan Dismenore dengan Kejadian Anemia}

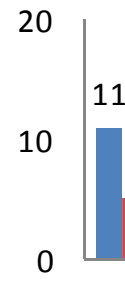

20 11

10

0

Pada hasil perhitungan dengan menggunakan uji statistik Somers'd didapatkan nilai $p=0,000$ $(\mathrm{p}<0,05),{ }^{8}$ dengan demikian dapat disimpulkan ada hubungan yang bermakna antara anemia dengan tingkat dismenore di SMA Muhammadiyah 3 Surakarta, sedangkan kekuatan korelasi (r) yaitu sebesar 0,426 yang menunjukkan bahwa kekuatan korelasinya sedang. Hal ini berarti terdapat 23 siswi yang tidak mengalami anemia dan 20 siswi dengan anemia. Dari 23 orang yang tidak mengalami anemia, terdapat 11 orang tidak mengalami dismenore.

Hal ini sesuai dengan teori bahwa kondisi anemia merupakan salah satu faktor yang berpengaruh terhadap tingkat dismenore pada saat menstruasi, karena terjadi iskemia yang merupakan suatu keadaan kekurangan oksigen pada jaringan yang bersifat sementara dan reversibel. Molekul yang berfungsi untuk mengikat dan membawa oksigen ke seluruh tubuh adalah hemoglobin. Semakin banyak hemoglobin yang mengikat dan membawa oksigen dalam sel darah merah maka kebutuhan oksigen pada jaringan akan terpenuhi. ${ }^{9}$ Iskemia dapat mengakibatkan dikeluarkannya fosfolipid, asam arakidonat, ion kalsium dan produksi prostaglandin dan vasopresin. Prostaglandin dan vasopresin akan menimbulkan vasokontriksi pembuluh darah arteri spiralis dan terjadinya iskemia endometrium bagian atas yang dapat mengeluarkan banyak fosfolipid sehingga dapat memicu pengeluaran prostaglandin lebih banyak, sampai akhirnya berakibat dismenore. ${ }^{3}$ Dismenore terjadi karena pengeluaran 
prostaglandin tertentu, prostaglandin $\mathrm{F} 2$ alfa dari sel-sel endometrium uterus. ${ }^{10}$

Setiap remaja putri yang setiap bulannya mengalami menstruasi secara otomatis mengeluarkan darah, itulah sebabnya setiap perempuan membutuhkan zat besi. Zat besi merupakan salah satu hal yang mengakibatkan dismenore. Kondisi anemia tersebut mempengaruhi aktivitas sehari-hari ${ }^{11}$ dan bisa terjadi penurunan konsentrasi belajar. ${ }^{12}$ Pada anak anemia berpotensi lebih besar terjadinya penurunan daya ingat dan rendahnya kemampuan pemecahan masalah yang akan berakibat buruk pada prestasi belajar. ${ }^{13}$

Pada hasil didapatkan responden yang tidak mengalami anemia, bisa mengalami tingkat dismenore ringan maupun sedang dan responden dengan anemia memiliki tingkat dismenore yang berbeda-beda yaitu ringan, sedang, berat, dan berat sekali. Hal ini sangat dimungkinkan karena masih banyak berbagai faktor penyebab terjadinya dismenore, selain anemia. Faktor penyebab lain di antaranya faktor kejiwaan dan endokrin. Faktor kejiwaan yang bisa terjadi, yaitu remaja dengan tingkat emosional yang tidak stabil. ${ }^{14}$ Faktor endokrin yang mempunyai hubungan dengan soal tonus dan kontraktilitas otot usus, karena endometrium dalam fase sekresi memproduksi Prostaglandin F2 yang menyebabkan kontraksi otot polos. Jika jumlah prostaglandin yang berlebihan dilepaskan ke dalam peredaran darah, maka menyebabkan dismenore. Penyelidikan dalam tahun terakhir menunjukkan bahwa peningkatan kadar prostaglandin memegang peranan penting pada etiologi dismenore primer. ${ }^{15}$

Selain faktor kejiwaan dan endokrin, terdapat faktor nyeri yang berpengaruh pada tingkat dismenore. Nyeri merupakan suatu bentuk rasa sensorik ketidaknyamanan yang bersifat subjektif dengan pengalaman emosional yang tidak menyenangkan. Sifat dan tingkat nyeri bervariasi tergantung dari ambang batas sakit seseorang. ${ }^{16}$

Berkaitan dengan kerusakan jaringan yang aktual yang dirasa sampai terjadi kerusakan. Nyeri merupakan campuran reaksi fisik, emosi, dan perilaku. Respon setiap orang dalam menyikapi nyeri sangat bervariatif. Toleransi terhadap nyeri juga berbeda antara orang satu dengan orang yang lain. Orang yang mempunyai tingkat toleransi tinggi terhadap nyeri tidak akan mengeluh nyeri dengan stimulus kecil. Sebaliknya, yang toleransi terhadap nyerinya rendah akan mudah merasa nyeri dengan stimulus nyeri kecil. Klien dengan tingkat toleransi tinggi terhadap nyeri mampu menahan nyeri tanpa bantuan. ${ }^{17}$

Hal ini sejalan dengan penelitian Sophia dengan menggunakan uji chi kuadrat diperoleh hasil $\mathrm{p}=0,043$, dapat disimpulkan terdapat hubungan yang bermakna antara status gizi dengan kejadian dismenore. Berdasarkan aspek fisik, status gizi sangat berpengaruh terhadap kualitas hidup individu. ${ }^{18}$

Status gizi yang rendah dapat diakibatkan karena asupan makanan yang kurang, termasuk zat besi yang dapat menimbulkan anemia. Anemia merupakan salah satu faktor yang menyebabkan kurangnya daya tahan tubuh terhadap rasa nyeri sehingga saat menstruasi terjadi dismenore. ${ }^{19}$

Berdasarkan hasil penelitian dan didukung dengan penelitian lain, maka dapat disimpulkan bahwa kondisi anemia dapat menjadi salah satu faktor penyebab terjadinya dismenore atau ada hubungan yang bermakna antara anemia dengan tingkat dismenore di SMA Muhammadiyah 3 Surakarta.

\section{Simpulan}

Simpulan dari penelitian ini adalah sebagian besar siswi tidak mengalami anemia dan sebagian besar remaja perempuan berada pada tingkat dismenore sedang. Dari hasil uji statistik Somers'd diperoleh hasil terdapat hubungan yang bermakna antara anemia dengan tingkat dismenore pada remaja putri di SMA Muhammadiyah 3 Surakarta dengan tingkat korelasi sedang.

\section{Daftar Pustaka}

1. Baziad A., Mohamad A., Prajitno P. Ilmu Kandungan Edisi Ketiga. Jakarta: PT. Bina Pustaka Sarwono Prawirohardjo, 2011.

2. Proverawati A., Siti M. Menarche Menstruasi Penuh Makna. Yogyakarta: Mulia Medika, 2009.

3. Gunatmaningsih D. Faktor-Faktor yang Berhubungan Dengan Kejadian Anemia Pada Remaja Putri di SMA Negeri I Kecamatan Jatibarang Kabupaten Brebes [skripsi]. Semarang: Universitas Negeri Semarang; 2007.

4. Ningsih, R. Efektifitas Paket Pereda Terhadap Intensitas Nyeri Pada Remaja dengan Dismenore di SMAN Kecamatan Curup [tesis]. Depok: Universitas Indonesia; 2011.

5. Sugiyono. Statistika Untuk Penelitian. Bandung: Alfabeta, 2014. 
6. Wiwid. Hubungan Anemia Dengan Dismenore Pada Mahasiswi Kebidanan Akbid Helvetia Pekanbaru [KTI]. Pekanbaru: Akbid Helvetia Pekanbaru; 2009.

7. Sukarni, I., Wahyu, P. Buku Ajar Keperawatan Matermitas. Yogyakarta: Nuha Medika, 2013.

8. Andarmoyo S. Konsep dan Proses Keperawatan Nyeri. Yogyakarta: Arruz Media, 2013.

9. Sophia F., Sori M., Jemadi. Faktor-Faktor yang Berhubungan dengan Dismenore pada Siswi SMK Negeri 10 Medan Tahun 2013 [tesis]. Medan: USU; 2013.

10. Yuniyanti, B., Masini, Salim, H.H.S. Hubungan Tingkat Stres dengan Tingkat Dysmenorrhoea Pada Siswi Kelas $X$ dan XI SMK Bhakti Karyakota Magelang. Jurnal Kebidanan. 2014; 3(7): 24-30.

11. Kurniawati, D., Kusumawati Y. Pengaruh Disminore Terhadap Aktivitas Pada Siswi SMK. Jurnal Kesehatan Masyarakat. 2011; 6(2): 93-9.

12. Singh A, Kiran D, Singh H, Nel B, Singh P dan Tiwari P. Prevalence and Severity of Dysmenorrhea: A Problem Related to Menstruation, Among First and Second Year Female Medical Students. Indian Journal Physiol Pharmacol. 2008; 52(4): 389-97.

13. Saadah, N., Santosa, B.J. Hubungan Kadar Hemoglobin Dengan Prestasi Belajar Siswa Kelas VII Di SMP
Negeri 2 Magetan. Jurnal Penelitian Kesehatan Suara Forikes. 2010; 1(4): 60-4.

14. Trimayasari. Kuswandi, Kadar. Hubungan Usia Menarche Dan Status Gizi Siswi SMP Kelas 2 Dengan Kejadian Dismenore. Jurnal Obstretika Scientia. 2014; 2 (2):192-211.

15. Bano R. Anemia and its impact on dysmenorrhea and Age at Menarche. Journal of Pharmacy and Biological Sciences. 2012; 4(2): 21-4.

16. Wahyuningsih, E, Puspitasari, L. Hubungan Kadar Hemoglobin Dengan Kejadian Dismenore Pada Siswi Kelas XI SMA Negeri 1 Wonosari Klaten. Jurnal Involusi Kebidanan. 2014; 4(7): 69-78.

17. Poornima S, Katti SM, Mallapur MD dan Vinay M. Gynecological Problems of Married Woman in the Reproductive Age Group of Urban Bergaum, Karnataka. Al Ameen Journal Medical Sciene. 2013; 6(3): 226-30.

18. Sytriani, S., Aryani, A. Konsumsi Makanan dan Kejadian Anemia pada Siswi Salah Satu SMP di Kota Makassar. Jurnal Kesehatan Masyarakat Nasiona; 4(6): 251-4.

19. Yang JH, Chen MJ, Chen CD, Chen CL, Ho HN dan Yang SY. Impact of Submucous Myoma on the Severity of Anemia. Elsevier. 2011; 95(5): 1769-72. 